\title{
Political Friction, Global Value Chains Linkages and Stock Price Volatility
}

\author{
Shuangjie $\mathrm{Li}^{1}$, Zhongyi $\mathrm{Li}^{1, *}$ \\ ${ }^{1}$ School of Economics and Management, Beijing University of Technology, Beijing, China \\ ${ }^{*}$ Corresponding author
}

Keywords: "Textbook Event”; Global Value Chains Linkages; Stock Price Volatility; "Quasi-natural Experiment”.

Abstract: This paper constructs a "quasi-natural experiment" using the impact of the "Textbook Event" in Japan in 2005 as the exogenous shock, examining the impact of political friction on stock prices of listed companies in China and exploring the internal transmission mechanism. The study finds that political friction between China and Japan has a negative impact on stock prices of Chinese listed companies trading with Japan. This effect is proven to be robust when accounting for a variety of robustness tests. The in-depth exploration of the transmission mechanism based on the mediating effect model finds that global value chains linkages are an important channel by which political friction influences stock prices.

\section{Introduction}

As a barometer for the national economic health, the stock market reflects the flow and allocation of social capital, and even affects the stability of the capital markets. The Chinese stock market experienced huge fluctuations in 2015. Within just a month, the A-share market lost nearly US\$ 3.5 trillion, which further caused global stock market fluctuation. Economic factors are the important factors affecting stock price volatility (Ftiti and Hadhri, 2019), but the political events such as terrorist attacks and political frictions also affect the stock market. According to data released by the Global Peace Index Report 2016, the annual global death toll from the conflicts in 2016 has reached its highest level in 25 years. Does current political friction have an important impact on the current stock market volatility? What are the transmission channels? Along with the refinement of global intra-product specialization, the global value chains (GVC) linkages are gradually forming and developing in recent years. Economic entities are embedded into GVC, so the close-knit community of interests has formed by GVC linkages. GVC linkages have become a transmission channel of adverse shocks.

The "Textbook Event" in Japan in 2005 was an important historical event that played a key role in destroying the friendly Sino-Japanese relations. This paper builds a "quasi-natural experiment" using the influence of the 2005 "Textbook Event" in Japan as the exogenous shock, examining the impact of political friction on stock price volatility in China. If this impact exists, is it transmitted to Chinese listed companies by Chinese GVC linkages with Japan? Therefore, the transmission channels associated with GVC need to be further examined in this paper. 


\section{Literature Review}

The study estimates the impact of international political frictions on stock price volatility and explores the transmission channels associated with GVC. Therefore, the literature directly related to this study includes two aspects. One is the research on the impact of political frictions on a stock market, and the other is the research on transmission channels associated with GVC.

\subsection{Research on the impact of political friction on the stock market}

Many scholars believe that political conflict and frictions are important factors affecting stock market volatility and political friction has a significant impact on the global stock market. There is no consensus on the effect of political conflict on stock market, and there are still some different conclusions. Some researchers find that political friction plays a key role in amplifying the decline in the stock market. Frijns et al. (2012) point out that political friction reduces the degree of integration of the stock market. Others find that political friction has almost no negative effects on stock prices. Omar et al. (2017) find the serious international crises and wars increase the price of oil and bonds, which may avoid a sharp fall in stock prices during the international crisis.

\subsection{Research on transmission channels associated with GVC}

As for transmission channels associated with GVC, the scholars mainly focus on how business cycle co-movement is transmitted by GVC linkages. Vertical specialization is a very important measurement tool for GVC linkages. Ng (2010) finds that vertical specialization plays an active role in promoting the synergy between the business cycle co-movement of the two countries. Giovanni and Levchenko (2010) point out that vertical specialization is an important channel affecting the inter-industry cycle co-movement in the manufacturing industry. In addition, some scholars study the transmission channels of shocks or crises through GVC, but there have been no definite conclusions drawn on how the impact of the shock is transmitted by GVC. Gangnes et al. (2012) document that GVC may expand the impact of the financial crises along the value chains. Bems et al. (2011) find that the financial crisis causes a greater final trade decline while the intermediate goods trade decline is relatively minor.

In summary, there has been many quantitative research on the impact of political friction on stock prices. However, the relevant conclusions and transmission mechanism are uncertain in the current literature. This paper will conduct research based on the aforementioned issues. First, we construct a "quasi-natural experiment" using the impact of the "Textbook Event" in Japan in 2005 as the exogenous shock and examine the impact of political friction on stock price volatility in China. This method not only can solve the endogeneity problems, but also improve the accuracy of estimated value. Second, we examine the transmission mechanism of political friction on stock price volatility, and also expand on research by Fisman et al. (2012).

\section{Hypothesis Development}

Stock price volatility is impacted by the operating conditions of listed companies and investment behavior. From the perspective of listed companies, political friction may affect stock price volatility directly. Political friction often results in the government adjusting its economic policies, and more serious political conflicts may lead to economic sanctions or economic relations interruption. The adjustment of economic policy often directly leads to a change in the business environment. In serious cases, the change in economic policy could lead to a deterioration in business conditions and a decrease in stock prices. From the perspective of investors, political friction may affect investment behavior and psychological characteristics of the investors, which in turn affect the stock prices. Sometimes investors are not entirely rational and their emotions can 
affect their investment behavior (Kaplanski and Levy, 2010).Political friction may trigger national sentiment, such as "boycott of Japanese goods" after the Sino-Japanese Diaoyu Island Incident, thus affecting investment in related listed companies and resulting in stock price fluctuations.

GVC linkages have an amplification effect on the external shock in the value chains, or have an inhibitory effect on risks in the value chains. On the one hand, GVC have their own unique cascading effect. Therefore it can transmit the external shock from a value chain to the whole system. This means that the cascading effect magnifies the impact of international conflicts on the economy, which makes this influence more effective than before. Moreover, risk transfer effect of vertical specialization also makes the amplification effect of GVC linkages more obvious. With the development of vertical specializations, all economic entities embedded into GVC are linked together by cross-border intermediate goods trading ( $\mathrm{Li}$ and $\mathrm{Zhu}, 2006$ ). The adverse shocks can also be transmitted to many countries and regions through intermediate goods trading. On the other hand, the risk-sharing mechanisms may weaken the impact of adverse shocks by GVC linkages, so this mechanism may have a buffer effect on the external shock.

The "Textbook Event" is used to examine the impact of political friction on the stock prices of listed companies in China in this paper. In the context of the above theoretical background, the following hypothesis and corollary are constructed:

Hypothesis 1: The "Textbook Event" has a negative impact on stock prices of Chinese listed companies trading with Japan.

Hypothesis 2: The influence of the "Textbook Event" on Japanese firms may be transmitted to Chinese listed companies by GVC linkages.

\section{Data}

\subsection{Data sources}

According to the development of the "Textbook Event" evolution, we take March 14-April 28, 2005 as our event window. Daily closing prices of the Chinese listed companies are used to examine the impact of the "Textbook Event" because daily stock prices have two major characteristics including sensitivity and short-term volatility. Daily closing prices and other related data are from mainly three sources. (I) China Stock Market Trading \& Accounting Research Database (CSMAR). Data associated with Chinese listed companies are from CSMAR, such as stock prices, enterprise assets, Tobin's Q, and comprehensive leverage. (ii) Chinese Customs-Trade Statistics (CCTS). Numerous trade data between China with other countries come from CCTS. (iii) China International Friendship Cities Association (CIFCA). Whether the location of the enterprise is a friendship city with its trade partner is derived from CIFCA.

\subsection{Descriptive statistics}

To observe stock price volatility, we describe the changes in stock prices of Chinese listed companies trading with Japan before and after the "Textbook Event" using the mean of daily stock prices (Figure 1). The results indicate that the stock prices of Chinese listed companies trading with Japan maintain a downward trend in the two days after the "Textbook Event", while this downward trend is stronger in the next 20 days. Meanwhile, we also account for stock price trends for Chinese listed companies trading with the U.S., Germany, or South Korea during the same period. Compared with stock prices of Chinese listed companies trading with Japan, the stock prices of Chinese listed companies trading with these other countries maintain a growth trend in the 3-4 days after the event but these stock prices are still in a downtrend in the subsequent days. Their fluctuation trends are very similar to each other. 


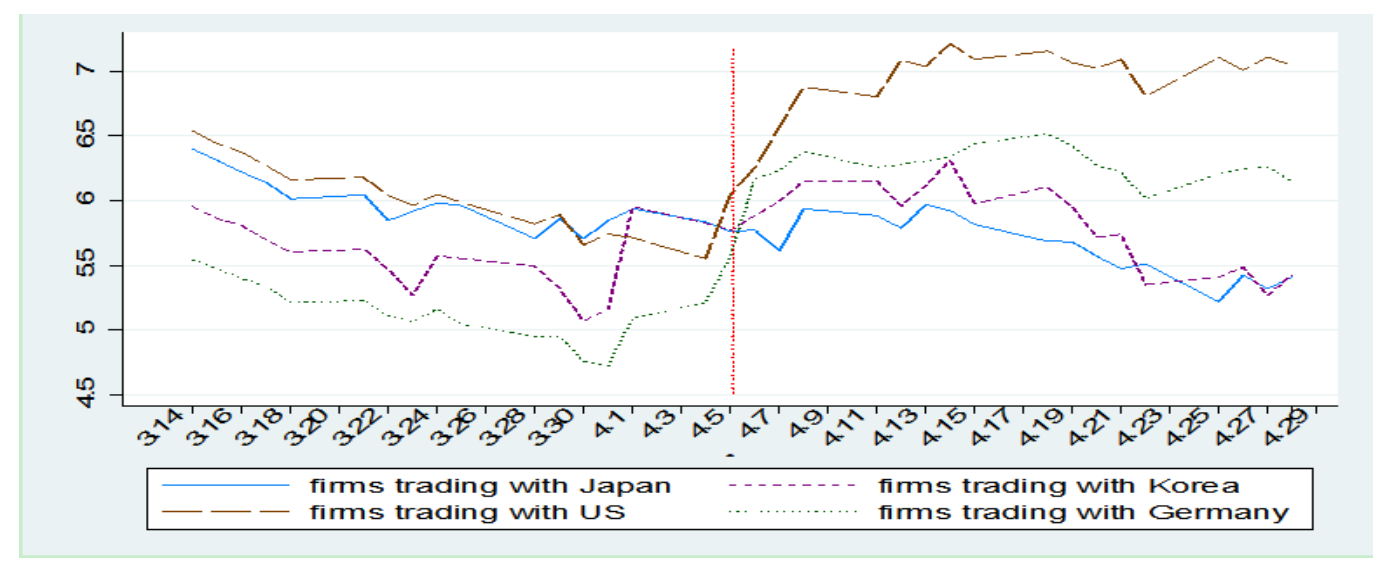

Figure1. Stock price fluctuation

According to the stock prices trend in Figure 1, this event has a more obvious negative impact on stock prices of Chinese listed companies trading with Japan, relative to Chinese listed companies trading with the U.S., Germany, and South Korea.

\section{Model and Empirical Results}

\subsection{Model}

The impact of the "Textbook Event” on stock prices of Chinese listed companies is evaluated by running the following regression:

$$
P_{i j, t}=\beta_{0}+\beta_{1} \text { Post }_{t}+\gamma \mathrm{X}+\delta_{i j}+\varepsilon_{i j, t}
$$

where $P_{i j, t}$ is daily closing price of a Chinese listed firm $i$ trading with country $j$ at day $t$; Post $t_{t}$ is a dummy variable for time, its value is one if the date is the day of the event or after the event, otherwise its value is zero; $\mathrm{X}$ is a set of control variables; $\delta_{i j}$ is the firm fixed effects; $\varepsilon_{i j, t}$ is an error term. Control variables include comprehensive leverage, enterprise size ,Tobin's Q, trade share and friendship cities. Trade share is the share of trade with Japan in total trade as the control variables, measuring the degree of economic and trade exchanges between China and Japan.

\subsection{Baseline results}

Table 1 The impact of the “Textbook Event” on stock prices-OLS

\begin{tabular}{lcccccc}
\hline Variables & $(1)$ & $(2)$ & $(3)$ & $(4)$ & $(5)$ & $(6)$ \\
& JPN & JPN & JPN & US & GFR & KOR \\
\hline Post & $-0.329^{* *}$ & $-0.254^{* * *}$ & $-0.181^{* * *}$ & -0.080 & -0.088 & -0.066 \\
& $(0.163)$ & $(0.024)$ & $(0.039)$ & $(0.069)$ & $(0.083)$ & $(0.071)$ \\
Control variables & Yes & Yes & Yes & Yes & Yes & Yes \\
Constant & $5.986^{* * *}$ & $5.705^{* * *}$ & $-21.076^{* * *}$ & $113.676^{* * *}$ & -31.878 & $68.524^{*}$ \\
& $(0.119)$ & $(0.123)$ & $(6.785)$ & $(40.294)$ & $(20.188)$ & $(38.405)$ \\
Firm fixed effects & No & Yes & Yes & Yes & Yes & Yes \\
$N$ & 2,165 & 2,165 & 1,727 & 717 & 372 & 423 \\
Adj R & 0.002 & 0.982 & 0.978 & 0.992 & 0.989 & 0.976 \\
\hline
\end{tabular}

*Significant at 10\%;**significant at 5\%;***significant at 1\%; Standard errors in parentheses.

Basing on Equation (1), the impact of the "Textbook Event" on stock prices of Chinese listed companies is examed. In Table 1, Column (1) presents the results without controls. The coefficient of "POST" is negative and statistically significant at the five-percent level, which indicates that this 
event causes the rapid decline in stock prices of Chinese listed companies trading with Japan. Firm fixed effects are added in Column (2). The results imply that this event still has a statistically significant impact. Control variables with firm characteristics or city characteristics are controlled in Column (3) and the results imply essentially the same level of impact. To explore the differences in this impact, we analyze stock price fluctuation of stock prices of listed companies trading with the U.S., Germany, or South Korea, respectively. Columns (4)-(6) reflect the "Textbook Event” has no significant impact on Chinese firms trading with the U.S., Germany, and South Korea.

\subsection{Endogeneity problems}

To solve endogeneity problems, the Difference-in-Difference (DID) approach is applied. Chinese listed companies trading with Japan are selected as the treatment group and Chinese listed companies trading with other countries are selected as the control group. The companies selected as the control group must meet two requirements. First, the degree of trade exchanges between trade Partner Country and China should be similar to that between Japan and China. Second, the degree of GVC between the country and China should be similar to that between China and Japan. Japan is one of China's important trading partners (Japan was China's fifth-largest trading partner in 2016), so GVC linkages between China and Japan is very high. To compare with listed companies trading with Japan, listed companies trading with the U.S., Germany, or South Korea are selected as the control group.

In this section, the DID method is applied to examine the impact of the "Textbook Event". Therefore, the estimation model based on the DID method is used:

$$
P_{i j, t}=\beta_{0}+\beta_{1} \text { Post }_{t}+\beta_{2} \text { Treat }_{i j} \times \text { Post }_{t}+\beta_{3} \text { Treat }_{i j}+\gamma X+\delta_{i j}+\varepsilon_{i j, t}
$$

where Treat $_{i j}$ is the dummy variable, taking a value of one if the group is a treatment group; the coefficient $\beta_{2}$ of the cross-term measures the change of the treatment group compared with the control group before and after the "Textbook Event".

Table 2 The impact of the “Textbook Event” on stock prices-DID

\begin{tabular}{lccccc}
\hline Variables & $\begin{array}{c}\text { DID } \\
(1)\end{array}$ & $\begin{array}{c}\text { DID } \\
(2)\end{array}$ & $\begin{array}{c}\text { DID } \\
(3)\end{array}$ & $\begin{array}{c}\text { DID } \\
(4)\end{array}$ & $\begin{array}{c}\text { PSM+DID } \\
(5)\end{array}$ \\
& JPN-US & JPN-GER & JPN-KOR & JPN-US, GER, & JPN-Others \\
\hline Post & -0.094 & -0.068 & $-0.157^{* *}$ & $-0.208^{* * *}$ & $-0.185^{* * *}$ \\
& $(0.060)$ & $(0.066)$ & $(0.066)$ & $(0.037)$ & $(0.026)$ \\
Post×Treat & $-0.174^{* * *}$ & $-0.113^{*}$ & $-0.153^{* *}$ & $-0.093^{* *}$ & $-0.099^{* * *}$ \\
& $(0.064)$ & $(0.068)$ & $(0.071)$ & $(0.045)$ & $(0.036)$ \\
Treat & $0.358^{* * *}$ & $-2.856^{* * *}$ & $0.431^{* * *}$ & $0.394^{* * *}$ & $-4.245^{* * *}$ \\
& $(0.098)$ & $(0.348)$ & $(0.074)$ & $(0.059)$ & $(0.606)$ \\
Control variables & Yes & Yes & Yes & Yes & Yes \\
Constant & $-10.444^{* *}$ & $-28.628^{* * *}$ & -4.101 & $-9.530^{* *}$ & $11.354^{*}$ \\
& $(5.094)$ & $(5.503)$ & $(5.400)$ & $(4.738)$ & $(6.694)$ \\
Firm fixed effects & Yes & Yes & Yes & Yes & Yes \\
$N$ & 2,352 & 2,115 & 2,340 & 3,156 & 3,494 \\
Adj R ${ }^{2}$ & 0.988 & 0.978 & 0.987 & 0.987 & 0.989 \\
\hline
\end{tabular}

*Significant at 10\%;**significant at 5\%;***significant at 1\%; Standard errors in parentheses.

The impact is examined based on Equation (2) and Table 2 displays the results. In Columns (1)-(3), Chinese listed companies trading with the U.S., Germany or South Korea are selected respectively as the control group. The DID estimator indicates that the "Textbook Event" has a negative impact 
on stock prices of Chinese listed companies trading with Japan relative to stock prices of Chinese listed companies trading with the U.S., Germany or South Korea , respectively. In Column (4), all Chinese listed companies trading with the U.S., Germany, or South Korea are combined as a new control group. The results suggest that stock price of Chinese listed companies trading with Japan has an obvious drop compared with that of Chinese listed companies no trading with Japan after the “Textbook Event”. This observation also proves that Hypothesis 1 is established.

\subsection{Robustness test}

To prove whether the aforementioned conclusions are robust, the robustness testing is completed, which includes using the matched sample and lagged variables.

\subsubsection{Using the new matched sample}

Chinese listed companies trading with the U.S., Germany, and South Korea are selected as the control group in the previous section. But there may be some errors in selecting these countries as the control group. Rosenbaum and Rubin (1983) proposed the propensity score matching (PSM) method. The PSM method can remove sample selection bias when it is employed to examine the impact of an event or a policy. Therefore, a new control group is matched by the PSM method to test this impact and the results are reported in Column (5) of Table 2.The results show that this event leads to a decline in stock prices of Chinese listed companies trading with Japan.

\subsubsection{Accounting for time lag effect}

Table 3 The impact on stock prices based on the time-lag effect

\begin{tabular}{lcccccc}
\hline Variables & FE & FE & FE & PSM+DID & PSM+DID & PSM+DID \\
& $(1)$ & $(2)$ & $(3)$ & $(4)$ & $(5)$ & $(6)$ \\
& Lag 1 & Lag 2 & Lag 3 & Lag 1 & Lag 1 & Lag 3 \\
\hline Post & $-0.176^{* * *}$ & $-0.159^{* * *}$ & $-0.117^{* * *}$ & $-0.186^{* * *}$ & $-0.176^{* * *}$ & $-0.170^{* * *}$ \\
& $(0.039)$ & $(0.039)$ & $(0.039)$ & $(0.026)$ & $(0.026)$ & $(0.025)$ \\
Post×Treat & & & & $-0.105^{* * *}$ & $-0.093^{* * *}$ & $-0.085^{* *}$ \\
& & & & $(0.036)$ & $(0.036)$ & $(0.035)$ \\
Treat & & & & $-24.756^{* * *}$ & $-25.069^{* * *}$ & $-25.059^{* * *}$ \\
& & & & $(0.423)$ & $(0.421)$ & $(0.410)$ \\
Control variables & yes & yes & yes & yes & yes & yes \\
Constant & $-19.333^{* * *}$ & $-23.451^{* * *}$ & $-26.482^{* * *}$ & $32.369 * * *$ & $36.312^{* * *}$ & $38.286^{* * *}$ \\
& $(6.714)$ & $(6.750)$ & $(6.754)$ & $(7.598)$ & $(7.556)$ & $(7.358)$ \\
Firm fixed affect & yes & yes & yes & yes & yes & yes \\
$N$ & 1,698 & 1,668 & 1,637 & 3,439 & 3,378 & 3,325 \\
Adj R ${ }^{2}$ & 0.979 & 0.979 & 0.980 & 0.990 & 0.990 & 0.991 \\
\hline
\end{tabular}

*Significant at 10\%;**significant at 5\%;***significant at 1\%; Standard errors in parentheses.

The impact of an event may exist, but the time lag effect might also affect when this change might occur. The impact of an event may exist the time lag effect. In other words, the effect transfer process of political friction may exist a certain time lag. Therefore, the stock prices may not be affected immediately by current events. Based on the aforementioned concerns, the next step is to examine whether this impact has a time lag effect. Stock prices with lag times 1, 2, and 3 days are selected as the explained variables and apply the fixed-effect model to examine the impact based on Equation (1). Columns (1)-(3) of Table 3 imply that stock prices with a time lag of between 1 and 3 days of Chinese listed companies trading with Japan go down under the influence of the "Textbook 
Event”. Besides that, the DID method is used to re-examining the impact and Columns (4)-(6) of Table 3 display the results. The results are still consistent with the previous conclusions, so the above conclusions are confirmed to be robust.

\subsection{Testing the transmission channels}

To test the transmission mechanism associated with GVC linkages, the mediating effect model is used to examine the impact of political friction on stock price volatility in this section, and the following regression equations are used:

$$
\begin{aligned}
& P_{i j, t}=\beta_{0}+\beta_{11} \text { Post }_{t}+\beta_{12} \text { Treat }_{i j} \times \text { Post }_{t}+\beta_{13} \text { Treat }_{i j}+\gamma \mathbf{X}+\delta_{i j}+\varepsilon_{i, t} \\
& \text { GVC }_{i j}=\beta_{0}+\beta_{21} \text { Post }_{t}+\beta_{22} \text { Treat }_{i j} \times \text { Post }_{t}+\beta_{23} \text { Treat }_{i j}+\gamma \mathbf{X}+\delta_{i j}+\varepsilon_{i j, t} \\
& P_{i j, t}=\beta_{0}+\beta_{31} \text { Post }_{t}+\beta_{32} \text { Treat }_{i j} \times \text { Post }_{t}+\beta_{33} \text { Treat }_{i j}+\beta_{34} \text { GVC }_{i j}+\gamma \mathbf{X}+\delta_{i j}+\varepsilon_{i j, t}
\end{aligned}
$$

where $G V C_{i}$ is expressed as the share of the intermediate goods trade relative to total trade in Equations (4)-(5).

In Columns (1)-(3) of Table 4, the impact is estimated respectively based on Equations (3)-(5). In Column (1), the results show the event plays a negative role in stock prices of listed companies trading with Japan. In Column (2), we examine the impact of political friction on GVC linkages based on Equation (4). These results show that political friction leads to the decline in GVC linkages. In Column (3), the results based on Equation (5) indicate that GVC linkages between the two counties are transmission channels by which the event plays a negative role in stock prices of listed companies trading with Japan. This proves that Hypothesis 2 is established.

Table 4. Testing transmission channels

\begin{tabular}{lccc}
\hline Variables & $(1)$ & $(2)$ & $(3)$ \\
& Stock price & GVC Linkage & Stock price \\
\hline Post & $-0.209^{* * *}$ & $0.027^{* * *}$ & $-0.215^{* * *}$ \\
& $(0.037)$ & $(0.007)$ & $(0.037)$ \\
Post×Treat & $-0.094^{* *}$ & $-0.072^{* * *}$ & $-0.077^{*}$ \\
& $(0.045)$ & $(0.009)$ & $(0.045)$ \\
GVC Linkages & & & $0.236^{* * *}$ \\
& & & $(0.090)$ \\
Treat & $0.364^{* * *}$ & $0.059^{* * *}$ & $0.350^{* * *}$ \\
& $(0.059)$ & $(0.012)$ & $(0.059)$ \\
Control variables & Yes & Yes & Yes \\
Constant & $-11.163^{* *}$ & 0.472 & $-11.274^{* *}$ \\
& $(4.698)$ & $(0.942)$ & $(4.694)$ \\
Firm fixed effects & Yes & Yes & Yes \\
$N$ & 3,156 & 3,156 & 3,156 \\
Adj R & 0.987 & 0.944 & 0.987 \\
\hline
\end{tabular}

*Significant at $10 \% ; * *$ significant at 5\%;***significant at 1\%; Standard errors in parentheses.

\section{Conclusion}

With the development of GVC, the impact of stock market volatility on a domestic economy and global stock market has been rapidly increasing. Under political friction, we explore the reasons for stock price volatility and examine its internal influence mechanism. We construct a "quasi-natural experiment" using the "Textbook Event" in Japan that occurred in 2005, examining the impact of 
political friction on stock prices of Chinese listed companies trading with Japan. These results show that Sino-Japanese political friction has a direct negative impact on stock prices in China. The results are robust when accounting for a variety of robustness tests. Further research on influence mechanisms shows that GVC linkages are important transmission channels for political friction to affect stock prices.

There are some directions for future research. First, stock price is only one dimension to evaluate the economic effect of political friction, so we can further analyze the impact of political friction on export quality, enterprise innovation or global value chain upgrading in the future. Second, this paper only examines the short-term effects of political friction on stock prices, but does not examine whether political friction has a long-term effect on stock prices, so future studies will examine the dynamic effects of political friction. Third, whether there is the difference in impact of political friction on incumbents and new companies is also a good direction.

\section{References}

[1] Bems, R., Johnson, R.C., Yi, K.-M., 2011. Vertical Linkages and the Collapse of Global Trade. J. American Economic Review. 101(3), 308-312.

[2] Fisman, R.J., Hamao, Y., Wang, Y., 2012. The Impact of Cultural Aversion on Economic Exchange: Evidence from Shocks to Sino-Japanese Relations. J. SSRN Electronic Journal.

[3] Frijns, B., Tourani-Rad, A., Indriawan, I., 2012. Political Crises and the Stock Market Integration of Emerging Markets. J. Journal of Banking \& Finance. 36(3), 644-653.

[4] Ftiti, Z., Hadhri, S., 2019. Can Economic Policy Uncertainty, Oil Prices, and Investor Sentiment Predict Islamic Stock Returns? A Multi-scale Perspective. J. Pacific-Basin Finance Journal. 53, 40-55.

[5] Gangnes, B., Ma, A.C., Van Assche, A., 2012. Global Value Chains and the Transmission of Business Cycle Shocks. J. SSRN Electronic Journal.

[6] Giovanni, D. J., Levchenko, A.A., 2010. Putting the Parts Together: Trade, Vertical Linkages, and Business Cycle Comovement. J. American Economic Journal: Macroeconomics. 2(2), 95-124.

[7] Kaplanski, G., Levy, H., 2010. Sentiment and Stock Prices: The Case of Aviation Disasters. J. Journal of Financial Economics. 95(2), 174-201.

[8] Li, X., Zhu, Z., 2006. International Trade, R\&D Spillover and Productivity Development. J. Economic Research Journal. (2), 31-43(in Chinese).

[9] Ng, E.C.Y., 2010. Production Fragmentation and Business-cycle Comovement. Journal of International Economics. J. 82(1), 1-14.

[10] Omar, A.M.A., Wisniewski, T.P., Nolte, S., 2017. Diversifying away the Risk of War and Cross-border Political Crisis. J. Energy Economics. 64, 494-510.

[11] Rosenbaum, P.R., Rubin, D.B., 1983. The Central Role of the Propensity Score in Observational Studies for Causal Effects. J. Biometrika, 70(1):41-55. 